\title{
India begins work on tidal energy A brief description of the projects being considered Present status of studies in India
}

\author{
L'Inde se lance dans l'énergie marémotrice \\ Description rapide des projets envisagés \\ Organisation actuelle des études en Inde
}

\author{
H. R. Sharma
}

Director Tidal Power Cell

Central Electricity Authority

India

The development of Tidal Power has been receiving attention in a small and sporadic way for the past many years in India.

The possibilities of Tidal Power Development have so far been identified at three locations in the country, viz.

- the Gulf of Kachchh

- the Gulf of Cambay, on the West Coast in Gujarat

- Sundarbans along the East Coast in the West Bengal.

A major step towards quantifying the overall possibilities of Tidal Power in India was taken by the erstwhile Central Water and Power Commission in 1975 when the services of an expert, Prof. E.M. Wilson of University of Salford U.K. were obtained under UNDP Programme. Prof. Wilson suggested four alternatives schemes in the Gulf of Kachchh and two alternative schemes in the Gulf of Cambay. Besides, three smail schemes were also indicated in the delta of Sundarbans.

The projects in the Gulf of Kachchh and Gulf of Cambay as identified by Prof. Wilson, however, involved large magnitude of civil works.

Subsequently, an alternative medium scale development in the Gulf of Kachchh was identified by Central Electricity Authority which was also appreciated by Prof. Wilson during later discussions.

This proposal envisages single effect single basin development by constructing the main barrier of about $3 \mathrm{~km}$ length across Hansthal Creek and two small barriers of about $1 \mathrm{~km}$ each across Sara and Phang Creeks.

A low bund/dyke of approximately 2 to $3 \mathrm{~m}$ height would also be necessary across the Sathsiada bet which gets submerged during high water.
L'utilisation de l'énergie marémotrice avait reçu dans les années passées en Inde une modeste et sporadique attention.

Trois sites ont été jusqu'ici localisés :

- le Golfe de Kutch

- le Golfe de Cambay, sur la côte Ouest du Gujarat

- le delta de Sundarbans, sur la côte Est, dans l'Ouest Bengal.

Une étape essentielle dans l'évaluation des possibilités de l'Inde en énergie marémotrice a été franchie par l'ancienne "Commission Centrale pour l'eau et l'énergie" lorsqu'elle a obtenu le concours du Prof. E.M. Wilson de l'Université de Salfort (U.K.) au titre d'un Programme de l'Office de coopération technique des Nations Unies (UNDP). Le professeur Wilson suggéra quatre variantes d'aménagement pour le golfe de Kutch, deux variantes pour le golfe de Cambay et trois petits aménagements dans le delta de Sundarbans.

Les projets du golfe de Kutch et du golfe de Cambay identifiés par le Prof. Wilson exigeaient des travaux de génie civil très importants.

C'est pourquoi la "Central Electricity Authority" (CEA) a proposé une variante, à une échelle intermédiaire, que le Prof. Wilson a jugé favorablement au cours de discussions ultérieures.

Cette proposition prévoit un simple bassin exploité en simple effet et délimité par un barrage principal d'environ $3 \mathrm{~km}$ de long à travers Hansthal Creek et deux petits barrages d'environ $1 \mathrm{~km}$ chacun à travers Sara et Phang Creeks.

Il sera en outre nécessaire de construire une digue de 2 ou 3 mètres de haut sur le banc Sathsiada qui est recouvert par les plus hautes eaux. 
The barriers would be connected to the high ground on either side to provide a permanent roadway across the Gulf thereby reducing considerable time \& cost of travel.

The power plant with an installed capacity of $600 \mathrm{MW}$ apprx. is proposed to be constructed in the Main barrier across Hansthal Creek (fig. 1).

\section{High Powered Commitees \& Tidal Power Cell}

The Government of India have sanctioned an estimate amounting to Rs.218,38 lakhs for carrying out the investigations and studies which would lead to the preparation of preliminary feasibility report for the Tidal Power Project in the Gulf of Kachchh.

The Government has also set up two High Powered Committees viz

- Technical Coordination Committee under the Chairmanship of Member (HE).

- Central Electricity Authority and Project Advisory/ Review Committee under the Chairmanship of Secretary (Energy) Department of Power.

The Tidal Power Cell has already started functioning in CEA which would coordinate the work relating to the investigations/studies.

Various cooperating agencies such as:

- Central Water \& Power Research Station;

- Survey of India;

- Naval Hydrographic Office;
Les barrages seront prolongés de part et d'autre du golfe par des digues jusqu'au delà des plus hautes eaux de manière à créer une voie routière permanente en travers du golfe réduisant ainsi considérablement le temps et le coût du voyage.

L'usine avec une puissance équipée de $600 \mathrm{MW}$ environ serait incluse dans le barrage principal à travers Hansthal Creek (fig. 1).

\section{Hauts comités et cellule marémotrice}

Le Gouvernement Indien a approuvé un budget de 21,838 millions de Roupies pour les études et investigations nécessaires à l'établissement d'un rapport préliminaire de faisabilité pour le projet d'usine marémotrice de Kutch.

Le Gouvernement a aussi créé deux hauts comités :

- un comité de coordination technique placé sous la Présidence du Membre du Conseil pour l'hydro-électricité au CEA

- un comité consultatif et de contrôle placé sous la Présidence du Secrétaire à l'Energie (Ministère de l'Energie).

La cellule marémotrice a déjà commencé à assurer à l'intérieur $d u$ CEA son travail de coordination des études et des investigations.

Différents organismes ont déjà été approchés pour effectuer les études et investigations tels que:

- Central Water and Power Research Station (Poona);

- Survey of India ;

- Naval Hydrographic Office;

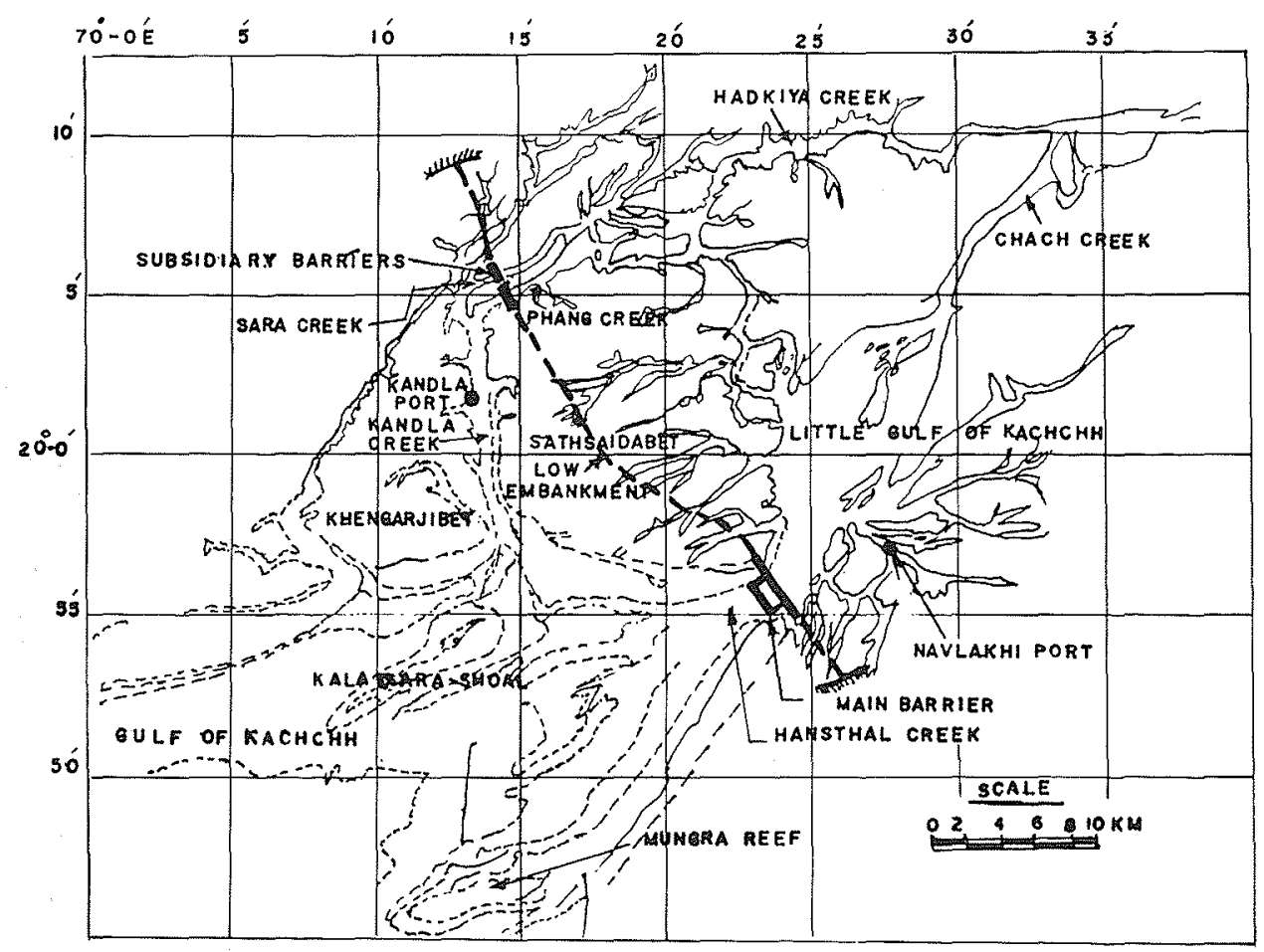

Figure 1 - Proposed tidal power project in the Gulf of Kachchh. 
- Geological Survey of India;

- Central Water Commission;

- Kandla Port Trust;

- Gujarat Electricity Board;

- Central Design Organisation (Gujarat)

have already been approached for carrying out the investigations and studies.

\section{Commencement of Investigations \& Seminar on Tidal Power}

The commencement of investigations for the tidal power project in the Gulf of Kachchh was formally inaugurated by the Minister of State for Energy at Kandla on 9 th January, 1982. On this occasion a Seminar on Tidal Power Development in India was also organised. The inaugural function was presided over by the Chief Minister of Gujarat.

Besides the distinguished guest and the representatives of various cooperating agencies a large number of engineers, scientists, journalists and interested public men attended the inaugural function and participated in the Seminar.

\section{Agreement with Electricité de France}

Since the proposed investigations/studies for the Tidal Power Project in the Gulf of Kachchh are of highly specialised nature and are being carried out for the first time in the country, the Central Electricity Authority has entered into an agreement with Electricite de France for seeking their assistance in the planning of the investigations in determining its scope and in identifying the broad areas and methodology for data collection.

The EDF Experts visited India from 14 th March to 3 rd April, 1982.
- Geological Survey of India ;

- Central Water Commission;

- Komdla Port Trust

- Gujarat Electricity Board;

- Central design organisation (Gujarat).

\section{Lancement des observations et Séminaire sur l'énergie marémotrice}

Le lancement des investigations pour le projet d'une usine marémotrice a été inauguré officiellement par le Ministre d'Etat pour l'Energie à Kandla le 9 janvier 1982. $A$ cette occasion, un séminaire sur l'énergie marémotrice en Inde a été organisé. La séance inaugurale a été présidée par le Premier Ministre du Gujarat.

Outre les hotes $d$ honneur et les représentants des organismes intervenant dans les études, un grand nombre d'ingénieurs, scientifiques, journalistes et personnalités politiques ont assisté à la séance inaugurale et ont participé au séminaire.

\section{Accord avec Electricité de France}

En raison de la nature très particulière des investigations et des études à effectuer pour la première fois en Inde, pour le projet d'une usine marémotrice, la "Central Electricity Authority" a conclu avec Electricité de France un accord d'assistance sur le programme des observations, la définition de leurs objectifs, l'extension et la méthodologie de la collecte des données.

Les Experts d'EDF ont effectué une mission en Inde du 14 Mars au 3 Avril 1982. 